\title{
1 Composition of dissolved organic matter in groundwater
}

2 Krista Longnecker* and Elizabeth B. Kujawinski

3 Department of Marine Chemistry and Geochemistry, Woods Hole Oceanographic Institution, $4 \quad$ Woods Hole, MA 02543, USA

5 Revised version submitted to: Geochimica et Cosmochimica Acta

6 Date revision submitted: 15 February 2011

$7 \quad$ *Corresponding author. Mailing address: WHOI MS\#4, Woods Hole, MA 02543. Phone: (508)

8 289-2824. Fax: (508) 457-2164. E-mail: klongnecker@whoi.edu 
ABSTRACT

Groundwater constitutes a globally important source of freshwater for drinking water and

12 other agricultural and industrial purposes, and is a prominent source of freshwater flowing into

13 the coastal ocean. Therefore, understanding the chemical components of groundwater is relevant

14 to both coastal and inland communities. We used electrospray ionization coupled with Fourier-

15 transform ion cyclotron resonance mass spectrometry (ESI FT-ICR MS) to examine dissolved

16 organic compounds in groundwater prior to and after passage through a sediment-filled column

17 containing microorganisms. The data revealed that an unexpectedly high proportion of organic

18 compounds contained nitrogen and sulfur, possibly due to transport of surface waters from septic

19 systems and rain events. We matched 292 chemical features, based on measured mass:charge

$20(\mathrm{~m} / \mathrm{z})$ values, to compounds stored in the Kyoto Encyclopedia of Genes and Genomes (KEGG).

21 A subset of these compounds (88) had only one structural isomer in KEGG, thus supporting

22 tentative identification. Most identified elemental formulas were linked with metabolic pathways

23 that produce polyketides or with secondary metabolites produced by plants. The presence of

24 polyketides in groundwater is notable because of their anti-bacterial and anti-cancer properties.

25 However, their relative abundance must be quantified with appropriate analyses to assess any

26 implications for public health. 


\section{INTRODUCTION}

Groundwater is a globally important source of freshwater and as such, its composition is

31 critically important for several reasons. First, groundwater is used as drinking water and for a

32 variety of agricultural and industrial uses (e.g., MARGAT, 1994; ZEKTSER and EVERETT, 2004).

33 Groundwater can also be an abundant source of freshwater entering the marine environment

34 (Mulligan and Charette, 2006; MoORe, 2010), and it can carry high levels of inorganic

35 nutrients and other elements (SLOMP and VAN CAPPELLEN, 2004; SANTOS et al., 2009). These

36 inorganic nutrients can cause regional increases in primary production, decreases in the size of

37 seagrass beds, and ultimately play a role in the extent of coastal hypoxia (VALIELA et al., 1990;

38 Bowen et al., 2007; MoORE, 2010).

39 While many investigations have studied the transport and reactivity of inorganic ions

40 within groundwater, considerably less is known about the sources and concentrations of organic

41 matter in groundwater. Groundwater has variable concentrations of dissolved organic carbon

42 (SAÑUDO-WILHELMY et al., 2002; GOÑI and GARDNER, 2003), which fluctuate with changes in

43 flow rate (MONTLUÇON and SAÑUDO-WILHELMY, 2001), with seawater mixing in the subsurface

44 (BECK et al., 2007), and with microbial activity (PABICH et al., 2001). The $\delta^{13} \mathrm{C}$ and $\Delta^{14} \mathrm{C}$ values

45 of bulk organic carbon in groundwater are similar to the values for surface soils, and this

46 suggests that organic matter percolates through the soils to the subsurface (MURPHY et al., 1989;

47 WASSENAAR et al., 1990). However, the proportion of organic matter from surface soils varies

48 regionally (ROUTH et al., 2001; LAPWORTH et al., 2008). Organic matter can also be released

49 from the sediments through subsurface microbial activity (MURPHY et al., 1989; ARAVENA and

50 WASSENAAR, 1993; BUCKAU et al., 2000). 
There is limited information available on the composition of dissolved organic matter in

52 groundwater. Groundwater is known to contain both humic and fulvic acids which appear to be

53 released from sedimentary organic carbon found in the soil/subsurface matrix (WASSENAAR et

54 al., 1990; ARTINGER et al., 2000). Furthermore, free and combined biological monomers such as

55 neutral sugars and amino acids have been identified in groundwater, although they represent less

56 than 10\% of the total organic carbon (RouTH et al., 2001; CHAPELLE et al., 2009). Finally, the

57 presence of microorganisms has been linked to changes in the fluorescence characteristics of

58 organic matter in the subsurface (CHAPELLE et al., 2009). However, there has been no molecular

59 level assessment of the composition of organic matter in groundwater and this hinders our ability

60 to characterize its fate and reactivity.

61 The molecular level composition of dissolved organic matter can be assessed using

62 ultrahigh resolution mass spectrometry. In particular, electrospray ionization coupled with

63 Fourier-transform ion cyclotron resonance mass spectrometry (ESI FT-ICR MS) has proven

64 useful in characterizing organic matter composition in a wide array of environmental samples

65 (e.g., Sleighter and HAtCher, 2008; SchmidT et al., 2009; BhAtiA et al., 2010). This

66 technique preferentially detects compounds that are ionic in aqueous mixtures and often provides

67 sufficient mass accuracy and resolution to assign elemental formulas based on the mass

68 measurement alone (KUJAWINSKI and BEHN, 2006; KoCH et al., 2007). In the present project, we

69 provide information on the molecular level composition of organic matter in groundwater, and

70 link this composition with the metabolic pathways responsible for the production of specific

71 organic compounds.

72 We established an experimental setup designed to examine the impact of protozoan grazers

73 on the composition of dissolved organic matter in groundwater. Protozoan grazers affect bulk 
74 carbon cycling in the subsurface (MADSEN et al., 1991; KInNER et al., 2002; TsO and TAGHON,

75 2006; CunNINGHAM et al., 2009), although their role in altering the presence or absence of

76 specific organic compounds remains unknown. Laboratory experiments have identified organic

77 compounds that appear or disappear when specific protozoan grazers are cultured with model

78 bacterial organisms (KUJAWINSKI et al., 2004; GRUBER et al., 2006). However, assessing the

79 impact of protozoan grazers on the composition of dissolved organic matter in natural

80 ecosystems is more complex and requires establishing experimental conditions with and without

81 protozoan grazers. Therefore, our experiment was designed to allow us to test the hypothesis that

82 protozoan grazers have a significant impact on the composition of dissolved organic matter in

83 groundwater.

\section{METHODS}

\section{$85 \quad$ 2.1. Sampling site and experimental setup}

Groundwater was sampled from the freshwater zone of the aquifer at the Waquoit Bay

87 National Estuarine Research Reserve. The groundwater was continuously pumped from $2.4 \mathrm{~m}$

88 below the surface and then through cylinders $25 \mathrm{~cm}$ high and $7 \mathrm{~cm}$ wide which were filled with

89 autoclaved aquifer sediments to mimic in situ conditions. The flow rate of groundwater through

90 the cylinders was $30 \mathrm{ml} \mathrm{hr}^{-1}$ which resulted in an 8 hour residence time within the cylinders. In

91 half of the cylinders, groundwater was filtered with a $1 \mu \mathrm{m}$ filter to remove protozoan grazers;

92 the other half of the cylinders received unfiltered ('whole') groundwater. Groundwater was

93 allowed to flow through the sediment-filled cylinders for one month prior to the onset of the

94 experiment. The first day following this pre-conditioning period is designated as day zero, and

95 all sample collection during the present project starts on day zero. From day zero to day eleven 
96 of the project, the cylinders received uniformly-labeled ${ }^{13} \mathrm{C}$-acetate $\left(99 \%{ }^{13} \mathrm{CH}_{3}{ }^{-13} \mathrm{COOH}\right.$,

97 Cambridge Isotope Laboratories, Andover MA) such that the concentration of acetate in the

98 groundwater was $200 \mu \mathrm{M}$. Groundwater exiting the cylinders was collected in acid-washed low-

99 density polyethylene cubitainers which were kept cold in the dark by a recirculating water bath.

100 The cubitainers were returned to the lab every three to six days.

101 The present study considers five samples: one sample from the groundwater entering the

102 sediment-filled cylinders on day 30 of the experiment and four samples from groundwater

103 exiting the sediment-filled cylinders. Two of the samples are from the treatment with grazers

104 (day 0 and day 30), and two of the samples are from the treatment where grazers were removed

105 by filtration (also from day 0 and day 30). The samples collected on day 0 were collected before

106 acetate was added to the sediment-filled cylinders. In addition, data from the present project was

107 compared to Suwannee River fulvic acid (SRFA) which had been previously analyzed by our

108 laboratory in both positive and negative ion modes (KIDO SouLE et al., 2010).

\section{2.2. Analysis of discrete groundwater samples}

110 Unfiltered groundwater in the cubitainers was used to obtain the abundance of protozoan

111 grazers and for $\delta^{13} \mathrm{C}$ measurements. The abundance of protozoan grazers was obtained using

112 epifluorescence microscopy. Cells were first preserved with $0.05 \%$ (final concentration) alkaline

113 Lugol's solution, followed by $0.1 \%$ (final concentration) sodium thiosulfate, and finally $2 \%$

114 (final concentration) of borate-buffered formalin. Samples were incubated at $4{ }^{\circ} \mathrm{C}$ for 24 hours,

115 stained with DAPI (25 $\mu \mathrm{g} \mathrm{ml}^{-1}$ final concentration) for $10 \mathrm{~min}$, and then filtered onto black 0.8

$116 \mu \mathrm{m}$ polycarbonate filters (SHERR et al., 1993). Concentrations and carbon stable-isotopic ratios of

117 total organic carbon (TOC) and dissolved inorganic carbon (DIC) in the groundwater exiting the

118 cylinders were obtained with an O.I.-analytical 1010 TOC/TIC analyzer in series with a Europa 
119 20-20 mass spectrometer. The coefficient of variability between duplicate injections averaged

$120<1 \% . \delta^{13} \mathrm{C}$ values were reported relative to PeeDee belemnite using standard notation: $\delta^{13} \mathrm{C}$

$121 \quad(\%)=\left(R_{\text {sample }} / R_{\text {standard }}-1\right) * 1000$, where $R$ is the ratio of the heavy to light element. The $\delta^{13} \mathrm{C}$

122 values were converted to atom $\%{ }^{13} \mathrm{C}$ for ease of presentation.

\section{2.3. Extraction and analysis of dissolved organic matter (DOM)}

124 Prior to analysis of the concentration and composition of DOM, the bacterial community in 125 the groundwater was removed by filtration of groundwater through combusted $0.2 \mu$ m Anodisk 126 filters (Whatman). The concentration of dissolved organic carbon (DOC) was measured with a

127 Shimadzu TOC- $\mathrm{V}_{\mathrm{CSH}}$ total organic carbon analyzer. The coefficient of variability between 128 replicate injections was $<1 \%$. Comparisons to standards provided by Prof. D. Hansell (University 129 of Miami) were made daily.

130 DOM in groundwater is too dilute to directly analyze using ESI FT-ICR MS and we used a 131 solid phase extraction method to concentrate the DOM. The $0.2-\mu \mathrm{m}$ filtered water was acidified 132 and extracted using stacked $\mathrm{C}_{18} / \mathrm{SDB}$ resin disks, and eluted off the disks with $70 \%$ methanol as 133 previously described (KIM et al., 2003; KUJAWINSKI et al., 2009). Different extraction methods 134 may alter the measured chemical characteristics of DOM (KAISER et al., 2003; SCHWEDE135 THOMAs et al., 2005); a single extraction method was used throughout the present project to 136 minimize this issue. The combination of $\mathrm{C}_{18}$ and SDB should result in a higher extraction 137 efficiency than just $\mathrm{C}_{18}$. While we did not measure extraction efficiencies for the present project, 138 we estimate the DOM extraction efficiency is at least $40 \%$ based on previous research with 139 similar extraction resins (TREMBLAY et al., 2007; DitTMAR et al., 2008). We cannot speculate 140 about the composition of the dissolved organic matter we were not able to extract using the 
$141 \mathrm{C}_{18} / \mathrm{SDB}$ resin disks. A blank, consisting of acidified Milli-Q water, was processed and analyzed 142 along with the five samples described above.

143 Samples were analyzed in both positive and negative ion modes on a 9.4 T ESI FT-ICR

144 mass spectrometer at the National ICR Users' Facility at the National High Magnetic Field

145 Laboratory at Florida State University in Tallahassee FL as previously described (KUJAWINSKI et

146 al., 2009). Positive ion mode will preferentially ionize compounds with amines, which are

147 common in proteins. Negative ion mode will preferentially ionize carboxylic acids which are

148 common in lignins, humic acids, and some lipids. One hundred scans were co-added, Hanning

149 apodized, zero-filled once, and fast Fourier-transformed (SENKO et al., 1996a; SENKO et al.,

150 1996b). Spectra were internally calibrated with a series of compounds present in all spectra and

151 mass accuracy errors were approximately $0.5 \mathrm{ppm}$ after internal calibration. The noise level was

152 individually determined for each sample, and only peaks with a signal at least three times the

153 noise level were analyzed further. Each peak is a mass:charge $(\mathrm{m} / \mathrm{z})$ value which is the measured

154 mass of the observed ion divided by its charge. Spectra were aligned (MANTINI et al., 2007) to

155 generate a master list of $m / z$ values present in all spectra. Any $m / z$ values found in the blank were

156 removed from the rest of the dataset. Data were converted to neutral masses assuming a loss of

157 one proton $\left(\mathrm{H}^{+}\right)$in negative ion mode and addition of one sodium ion $\left(\mathrm{Na}^{+}\right)$in positive ion mode.

158 Elemental formulas were assigned using the Compound Identification Algorithm (CIA:

159 KUJAWINSKI and BEHN, 2006; KUJAWINSKI et al., 2009) using a formula error of 1 ppm, and a

160 relationship error of $20 \mathrm{ppm}$. The mass limit above which elemental formulas were assigned only

161 by functional group relationships was $500 \mathrm{Da}$. Elements considered in CIA are C, H, O, N, S,

162 and P. Isotopomers with a ${ }^{13} \mathrm{C}$ atom were identified and elemental formulas were corrected to

163 reflect ${ }^{13} \mathrm{C}$ content. ESI FT-ICR MS is not quantitative, and peak heights are affected by 
164 differences in ionization efficiency among compounds. Therefore we only consider the presence

165 or absence of a compound rather than relative peak heights. We could not do $\mathrm{MS}^{\mathrm{n}}$ to confirm the

166 structure/identity of individual $\mathrm{m} / \mathrm{z}$ values due to the high number of peaks observed at each

167 nominal mass.

\subsection{Computational and statistical analysis}

Three datasets were downloaded in February 2010 from the Kyoto Encyclopedia of Genes

170 and Genomes (KEGG, KANEHISA et al., 2008): biochemical compounds, biochemical reactions,

171 and a comprehensive list of metabolic pathways. This combination of KEGG datasets allows us

172 to identify metabolic pathways which are involved in the production or alteration of specific

173 biochemical compounds. The lists were imported into MATLAB, and the neutral masses for

174 each of the 16,143 biochemical compounds were recalculated using exact elemental masses.

175 Duplicate neutral masses were possible in this dataset due to the presence of structural isomers

176 and thus we compared the list of $m / z$ values from the present project to KEGG in two ways. First,

177 we looked for any compound listed in KEGG within 1 ppm of our neutral masses. Second, we

178 culled this list to consider only compounds found once in KEGG, i.e., those without structural

179 isomers. Figures of the metabolic pathways in KEGG with biochemical compounds found in the

180 present project were generated using the KEGG application programming interface via the

181 SOAP/WSDL web service from within MATLAB. Select metabolic pathways are provided in

182 the Electronic Annex as EA Figures 2 to 10. We recognize that our measured $m / z$ values cannot

183 be linked to KEGG compounds with absolute certainty due to the possibility of structural

184 isomers that are not included in KEGG. This caveat should be considered when we use the word

185 'compound' in the discussion of our data and KEGG. 

analyses were conducted for positive and negative ion modes. Distances between samples were calculated with the Bray-Curtis distance measure using the Fathom toolbox (David Jones,

189 University of Miami) and cluster analysis was performed using Ward’s linkage method 190 (McCunE and GRACE, 2002).

\section{RESULTS AND DISCUSSION}

Our experimental design was successful in reducing the number of protozoan grazers in the $1931 \mu \mathrm{m}$-filtered treatments. By day 30 of the experiment, the groundwater exiting the cylinders for

194 the whole treatments (with grazers) had $5880 \pm 610$ protozoan grazers $\mathrm{ml}^{-1}$. The groundwater 195 exiting the $1 \mu$ m-filtered treatments (grazers removed by filtration) had $1140 \pm 380$ protozoan 196 grazers $\mathrm{ml}^{-1}$.

197 The DOC concentrations in the groundwater prior to entering the sediment-filled cylinders 198 averaged $75.1 \mu \mathrm{M}(66.3$ to $83.9 \mu \mathrm{M}, 95 \%$ confidence interval, $\mathrm{n}=4)$. The concentration of DOC 199 exiting the cylinders increased to an average of $110.8 \mu \mathrm{M}(75.9$ to $145.6 \mu \mathrm{M}, 95 \%$ confidence 200 interval, $\mathrm{n}=27)$ in the cylinders receiving $1 \mu \mathrm{m}$-filtered groundwater and $146.8 \mu \mathrm{M}(95.4$ to $201198.2 \mu \mathrm{M}, 95 \%$ confidence interval, $\mathrm{n}=21$ ) in the cylinders receiving whole groundwater. The 202 increase in dissolved organic carbon concentrations in the cylinders which did not receive added 203 carbon was likely due to carbon leaching off the sediment within each cylinder, although we 204 cannot discount the contribution of DOC exuded by microbial cells within the cylinders. The atom $\%$ of ${ }^{13} \mathrm{C}$ of TOC in the groundwater increased rapidly after the addition of ${ }^{13} \mathrm{C}$ -

206 acetate, and then declined after the ${ }^{13} \mathrm{C}$-acetate addition was terminated on day 11 of the 207 experiment (Fig. 1). However, ${ }^{13} \mathrm{C}$-TOC includes both ${ }^{13} \mathrm{C}$-acetate added as dissolved organic 
208 carbon and any of the ${ }^{13} \mathrm{C}$-acetate assimilated into bacterial biomass. Our dissolved inorganic 209 carbon (DIC) data revealed increases in atom $\%{ }^{13} \mathrm{C}$ in DIC above the natural abundance of ${ }^{13} \mathrm{C}$

210 in both the whole and the $1 \mu \mathrm{m}$-filtered treatments (Fig. 1). The increase in DIC was measured at

211 the first sampling point following the addition of the ${ }^{13} \mathrm{C}$-labeled carbon and was sustained

212 throughout the duration of the experiment. The loss of carbon as DIC ranged from less than $1 \%$

213 to a maximum of $7 \%$ of all calculated losses. Therefore, the ${ }^{13} \mathrm{C}$-DIC data indicate the microbial

214 community within the sediment-filled cylinders was capable of utilizing the added organic

215 material.

216 We analyzed the groundwater exiting the sediment-filled cylinders using ultrahigh

217 resolution mass spectrometry (ESI FT-ICR MS) which provided insight into the molecular-level

218 composition of the groundwater in our experiment. ESI FT-ICR MS yielded between 3200 and

$2198300 \mathrm{~m} / \mathrm{z}$ values, with slightly more $\mathrm{m} / \mathrm{z}$ values observed in negative ion mode (Fig. 2, Table 1).

220 Although we observed organic compounds with ${ }^{13} \mathrm{C}$ replacing ${ }^{12} \mathrm{C}$ in the elemental formulas,

221 there was no increase in the proportion of ${ }^{13} \mathrm{C}$-compounds following the incubation of the

222 groundwater with ${ }^{13} \mathrm{C}$-acetate. Therefore, ${ }^{13} \mathrm{C}$-acetate was apparently not incorporated into new

223 molecules as groundwater was transported through the columns. There are multiple possibilities

224 for this observation. The most likely possibilities are that the ${ }^{13} \mathrm{C}$-labeled organic matter was

225 washed out of the columns between day 0 and day 30 of the experiment, or the bacterial

226 community respired all of the ${ }^{13} \mathrm{C}$-acetate. Methodological issues could have also limited our

227 ability to detect the ${ }^{13} \mathrm{C}$ compounds if they were present in concentrations below our detection

228 limit, or if the ${ }^{13} \mathrm{C}$ was present in molecules whose molecular mass was less than $\mathrm{m} / \mathrm{z} 300$.

229 Our hypothesis was that the presence of protozoan grazers would have a significant impact

230 on the composition of dissolved organic matter. We used both positive and negative ion modes to 
231 address this question because the different modes will preferentially ionize different compounds.

232 However, $45 \%$ of $\mathrm{m} / \mathrm{z}$ values in positive ion mode and $58 \%$ of $\mathrm{m} / \mathrm{z}$ values in negative ion mode

233 were found in all five samples. The overlap between samples is also evident in the Van Krevelen

234 diagrams used to visualize the O:C and $\mathrm{H}: \mathrm{C}$ molar ratios of each elemental formula (EA Figure

235 1). Furthermore, in positive ion mode the difference between the whole and filtered treatments

236 decreased during the incubation (Fig. 3). In negative ion mode, there were fewer $m / z$ values in

237 the treatment without grazers by the conclusion of the experiment (Table 1). The cluster analysis

238 also revealed that the compounds were different from those observed at the onset of the

239 experiment (Fig. 3). However, the level of differences between samples in negative ion mode

240 was quite small, with Bray-Curtis differences between samples ranging from 0.15 to 0.32 in

241 negative ion mode. Based on laboratory experiments, Gruber et al. (2006) conclude that the

242 bacterial community has a greater impact on the composition of dissolved organic matter than do

243 bacterial predators. While we do not have a bacteria-free treatment for comparison, our data do

244 not support our hypothesis that protozoan grazers affect the composition of dissolved organic

245 matter in groundwater on a 30-day timescale. Additional work will be needed to assess if grazers

246 were able to impact the abundance of specific compounds in groundwater; however, ESI FT-ICR

247 MS is not considered quantitative and for the remaining discussion we will consider the

248 composition of organic matter in the full data set rather than focusing on differences between

249 individual samples.

250 While compounds only containing $\mathrm{C}, \mathrm{H}$, and $\mathrm{O}$ were the most prevalent elemental

251 formulas assigned here, a larger than expected proportion of the $m / z$ values were assigned

252 formulas containing CHON. The percent of $\mathrm{CHON}$ formulas ranged from 15 to $38 \%$ in our

253 samples. This range is higher than that observed in marine and riverine samples collected off the 
254 eastern United States (KUJAWINSKI et al., 2009) and in freshwater samples from inland rivers

255 (SLEIGHTER et al., 2009). However, higher proportions of organic nitrogen compounds have been

256 observed in pore waters within offshore marine sediments (SCHMIDT et al., 2009) and from

257 glaciated surfaces in Greenland (BHATIA et al., 2010). The samples for the present project were

258 collected in an area where dissolved organic nitrogen is predominantly from septic systems

259 (Cole et al., 2006; KROEGER et al., 2006). Furthermore, the transformation of nitrogen from

260 organic to inorganic forms was correlated to the distance groundwater travels in the subsurface

261 (KROEGER et al., 2006). Therefore we posit that the high proportion of CHON compounds in our

262 dataset is due to limited microbial remineralization of dissolved organic nitrogen prior to the

263 groundwater reaching our study site. However, deciphering which biotic and abiotic processes in

264 these disparate environments may contribute to high proportions of CHON compounds will be

265 an exciting avenue for future research.

266 Sulfur-containing elemental formulas were also prevalent in the original groundwater

267 sample as CHONS in positive ion mode and in negative ion mode as CHOS (Table 1). Sulfur-

268 containing organic matter can be a dominant component of rainwater (ALTIERI et al., 2009)

269 which could percolate to the subsurface. In contrast, organic sulfur compounds are only a small

270 component of subsurface sedimentary organic matter (RYU et al., 2006). Although we cannot

271 definitively identify the source of the organic sulfur compounds in the present project, the

272 decrease in the proportion of these compounds in groundwater collected from the cylinder

273 terminus was striking. This suggests that organic sulfur compounds were consumed or

274 remineralized during transit through the cylinders. Organic sulfur compounds have been

275 recognized as both carbon and sulfur sources for marine microorganisms (SIMÓ et al., 2002;

276 SIEVERT et al., 2007) and sulfate-reducing bacteria have been found in subsurface microbial 
communities (VAN BEEK and VAN DER KOOIJ, 1982; CHANG et al., 2001). While sulfate-reducing

278 bacteria require an organic carbon source to reduce sulfate to sulfide, to our knowledge there has

279 been no investigation of the consumption or alteration of organic sulfur compounds by

280 subsurface microorganisms.

To characterize potential sources of organic matter, we compared our groundwater data

282 with metabolic pathways collated in KEGG. For this analysis, we considered $\mathrm{m} / \mathrm{z}$ values found in 283 any of the five groundwater samples, and therefore do not consider observations about individual

284 samples. As a control exercise, we compared the $m / z$ values in Suwannee River Fulvic Acid

285 (SRFA) to compounds in KEGG. We recognize that only a subset of organic compounds are 286 listed in KEGG, but putatively linking compounds in groundwater with metabolic pathways in

287 KEGG is one step towards linking organic compounds with biological sources. When the 288 measured $\mathrm{m} / \mathrm{z}$ values were converted to neutral masses, there were 292 compounds in the KEGG 289 database within 1 ppm of an $\mathrm{m} / \mathrm{z}$ value found within groundwater; 88 of those compounds did not 290 have any structural isomers in KEGG (EA Table 1). While this is a small number of compounds

291 relative to the $m / z$ values observed in all the samples, this project provides an important step 292 towards linking organic compounds detected in situ with biochemical pathways. The organic 293 compounds with no structural isomers were contained within 25 different metabolic pathways

294 (Table 2). For most of the metabolic pathways, additional metabolic intermediates were 295 tentatively identified in our dataset but these compounds contain structural isomers in KEGG and 296 so the identifications cannot be fully constrained. However, the possible presence of these 297 additional intermediates provides confidence that the metabolic pathway is active in our system 298 (SuHrE and SchmiTt-Kopplin, 2008). In some cases, up to half of the biochemical compounds 299 within a metabolic pathway were putatively identified in groundwater. The compounds within 
the biochemical pathways which were not identified within our samples are either not present or

301 are not amenable to measurement using ESI FT-ICR MS. Additional work will be needed to

302 determine the concentration of the compounds we observed in groundwater, and in the following

303 discussion we only consider the presence or absence of compounds. Two broad groups of

304 metabolic pathways (Table 2) were the majority of the $m / z$ values matched to KEGG: (1)

305 microbial pathways involved in the production of polyketides or other pharmaceutically

306 interesting compounds (biosynthesis of polyketides and terpenoids), and (2) pathways related to

307 plant-based metabolisms (biosynthesis of other secondary metabolites). The remaining pathways

308 (carbohydrate metabolism, lipid metabolism, amino acid metabolism, metabolism of cofactors

309 and vitamins, and xenobiotics biodegradation and metabolism) had no more than four

310 compounds without structural isomers and represent diverse classes of metabolic pathways.

311 Identification of polyketides in groundwater is an important finding because these

312 compounds affect human metabolism. Polyketides are a class of compounds used as anti-

313 bacterial and anti-cancer drugs, and are generally classified into three groups based on their

314 structure and/or their biosynthetic pathways (RAWLINGS, 2001; SHEN, 2003). In the present

315 project (Table 2), we found the strongest evidence for the biochemical pathways involved in the

316 biosynthesis of type II polyketides (EA Figure 2) and the biosynthesis of 12-, 14-, and 16-

317 membered macrolides, which are type I polyketides with macrocyclic lactone rings (EA Figure

318 3). Furthermore, while not quite half of the compounds in the pathway for the biosynthesis of

319 type II polyketides were also found in SRFA, none of the compounds in the pathway for the

320 biosynthesis of 12-, 14-, and 16-membered macrolides, tetracycline, or ansamycins were found

321 in SRFA. Fungi and bacteria, especially Actinomycetes, are the main producers of type II

322 polyketides (HUTCHINSON and FUJII, 1995), and type II polyketide synthase genes have 
323 previously been observed in soils (SEOW et al., 1997; WAWRIK et al., 2005). For some of the

324 polyketides, we observed elemental formulas consistent with intermediate metabolites in the

325 majority of the chemical steps needed to produce a polyketide (e.g., doxorubicin, auramycinone,

326 urdamycin A, urdamycin B; EA Figure 2). Identification of these biosynthetic intermediates

327 suggests that polyketides may be actively produced in the subsurface. However, we cannot

328 eliminate the possibility that polyketides are also being transported through the subsurface from

329 septic systems in the region.

330 Polyketides may be degraded by biota in the subsurface. In laboratory cultures, the fungus

331 Alternaria alternata has been shown to degrade the polyketides it produces (Jonsson et al.,

332 1987). Bacterial degradation of fungal polyketides has also been demonstrated for the polyketide

333 cercosporin (MitcheLL et al., 2002). For example, cercosporin is degraded by microorganisms

334 into xanosporic acid, through two intermediate steps (MiTCHELL et al., 2003; TAYLOR et al., 335 2006). Cercosporin, xanosporic acid, and one of the two intermediates were observed in all of

336 our groundwater samples, suggesting that this degradation pathway (or a similar one) is present

337 and active in our system.

338 The second major category of compounds identified in the present study is secondary

339 metabolites produced by plants (Table 2, EA Figures 4 to 10). In most of the biochemical

340 pathways, the compounds identified in KEGG without structural isomers were also identified

341 within SRFA. Quantification of fatty acids has revealed that plant-based organic matter can be a

342 dominant component of sedimentary organic matter in aquifers (HARTOG et al., 2004). Our

343 observation of specific compounds produced by plant-based metabolisms and the high degree of

344 overlap with compounds in SRFA highlights the impact of surface-based processes on the

345 subsurface organic matter. However, we cannot determine whether these plant metabolites are 
available to subsurface microbial communities and thus whether they are degraded there. While

347 the presence of plant-derived compounds in groundwater is not surprising, the observation

348 emphasizes that both micro- and macro-fauna have the potential to impact the composition of

349 dissolved organic matter in the subsurface.

350 Conclusions

The present project assessed the composition of dissolved organic matter in groundwater

352 and identified possible sources of a subset of the organic matter. We observed a higher

353 proportion of organic nitrogen and sulfur compounds compared to organic matter characterized

354 from other environments, possibly due to inputs from septic systems and rain events.

355 Furthermore, the appearance of degradation products of one polyketide, cercosporin, and ${ }^{13} \mathrm{C}$ -

356 labeled dissolved inorganic carbon indicates the bacterial community is capable of utilizing

357 organic compounds in groundwater. We also found evidence of microbial production of organic

358 compounds in the subsurface because a large proportion of intermediates within polyketide

359 biosynthetic pathways were present in groundwater. These latter compounds are of particular

360 relevance to communities that rely on groundwater as drinking water because the presence of

361 pharmaceutically-interesting compounds has unknown consequences. Our data do not include

362 the concentration of each compound, therefore we cannot assess the relevance to human health.

363 Additional research with compound-specific methods is needed in order to definitively identify

364 these compounds, and quantify any spatial and temporal variability in their concentrations.

Acknowledgments. We thank Meagan Eagle Gonneea for help installing the groundwater

367 well, Ann Mulligan for discussions about the project and the research site, Dave Harris at the

368 University of California, Davis for the analysis of the carbon stable isotopes, and Alan Marshall, 
369 Jerry Purcell and Tanner Schaub at the National High Magnetic Field Laboratory for access to 370 and assistance with the ultrahigh resolution mass spectrometer used in the present study. The

371 comments of three anonymous reviewers were helpful in improving the manuscript. Finally, we

372 extend our special gratitude to the Waquoit Bay National Estuarine Research Reserve for

373 allowing us to install the well and conduct this experiment in their boathouse. Funding was

374 provided by NSF grants EAR-0525166 and OCE-0751897 to EBK.

375 
378 Fig. 1. Atom $\%{ }^{13} \mathrm{C}$ of total organic carbon (TOC, squares) and dissolved inorganic carbon (DIC, 379 diamonds) in groundwater exiting the sediment-filled cylinders exposed to (A) whole 380 groundwater or (B) $1 \mu \mathrm{m}$-filtered groundwater. Dashed line indicates the natural abundance of $381{ }^{13}$ C. Data are plotted on a $\log _{10}$ scale.

382 Fig. 2. Negative ion mode mass spectra from whole groundwater sampled at day 30. The y-axis 383 is relative peak height. The dotted line is the peak detection threshold for this sample. Elemental 384 formulas are given above select peaks. The compound number(s), beginning with ' $\mathrm{C}$ ', are given 385 for compounds found in KEGG. Compounds with structural isomers in KEGG (marked with a 386 triangle) and without structural isomers (marked with a star) were both identified in the 387 groundwater samples.

388 Fig. 3. Cluster analysis based on Bray-Curtis distance measures calculated for the ultrahigh 389 resolution mass spectrometry data collected in (A) positive ion mode and (B) negative ion mode. 390 Note the different $\mathrm{x}$-axis scale for the two figures. 
392 Table 1. Samples were analyzed in positive and negative ion mode using ESI FT-ICR MS.

393 'Whole' and 'Filtered' in the sample column refer to whole groundwater and $1 \mu \mathrm{m}$-filtered 394 groundwater exiting the sediment-filled cylinders. The table summarizes the number of $m / z$

395 values found in each sample, the percent of $m / z$ values assigned elemental formulas, and the 396 percent of formulas containing only $\mathrm{CHO}, \mathrm{CHON}$, CHOS, or CHONS in the elemental formula.

\begin{tabular}{lllllll}
\hline Sample & $\begin{array}{l}\text { Total \# } \\
\text { m/z values }\end{array}$ & $\begin{array}{l}\text { \% } \mathrm{m} / \mathrm{z} \text { with } \\
\text { formulas }\end{array}$ & \%CHO & \%CHON & \%CHOS & \%CHONS \\
\hline Positive ion mode & & & & & & \\
\hline Whole, day 0 & 3941 & 97 & 41 & 38 & 2 & 3 \\
Filtered, day 0 & 3790 & 99 & 55 & 28 & 0 & 5 \\
Whole, day 30 & 4759 & 97 & 63 & 21 & 0 & 3 \\
Filtered, day 30 & 3260 & 96 & 66 & 23 & 0 & 1 \\
Groundwater, day 30 & 3368 & 98 & 35 & 15 & 2 & 20 \\
\hline Negative ion mode & & & & & & \\
\hline Whole, day 0 & 8329 & 94 & 48 & 31 & 3 & 2 \\
Filtered, day 0 & 6035 & 91 & 59 & 22 & 4 & 0 \\
Whole, day 30 & 4282 & 98 & 44 & 24 & 5 & 5 \\
Filtered, day 30 & 3376 & 99 & 64 & 26 & 0 & 0 \\
Groundwater, day 30 & 5915 & 94 & 45 & 24 & 10 & 7 \\
\hline
\end{tabular}


Table 2. Number of $m / z$ values matching compounds in the KEGG database, including compounds with and without structural isomers. Matches to compounds in KEGG are shown for the data from the present project ('Waquoit Bay') and Suwannee River Fulvic Acid ('SRFA').

401 The total number of compounds is the entire set of compounds contained in the metabolic

402 pathway at KEGG.

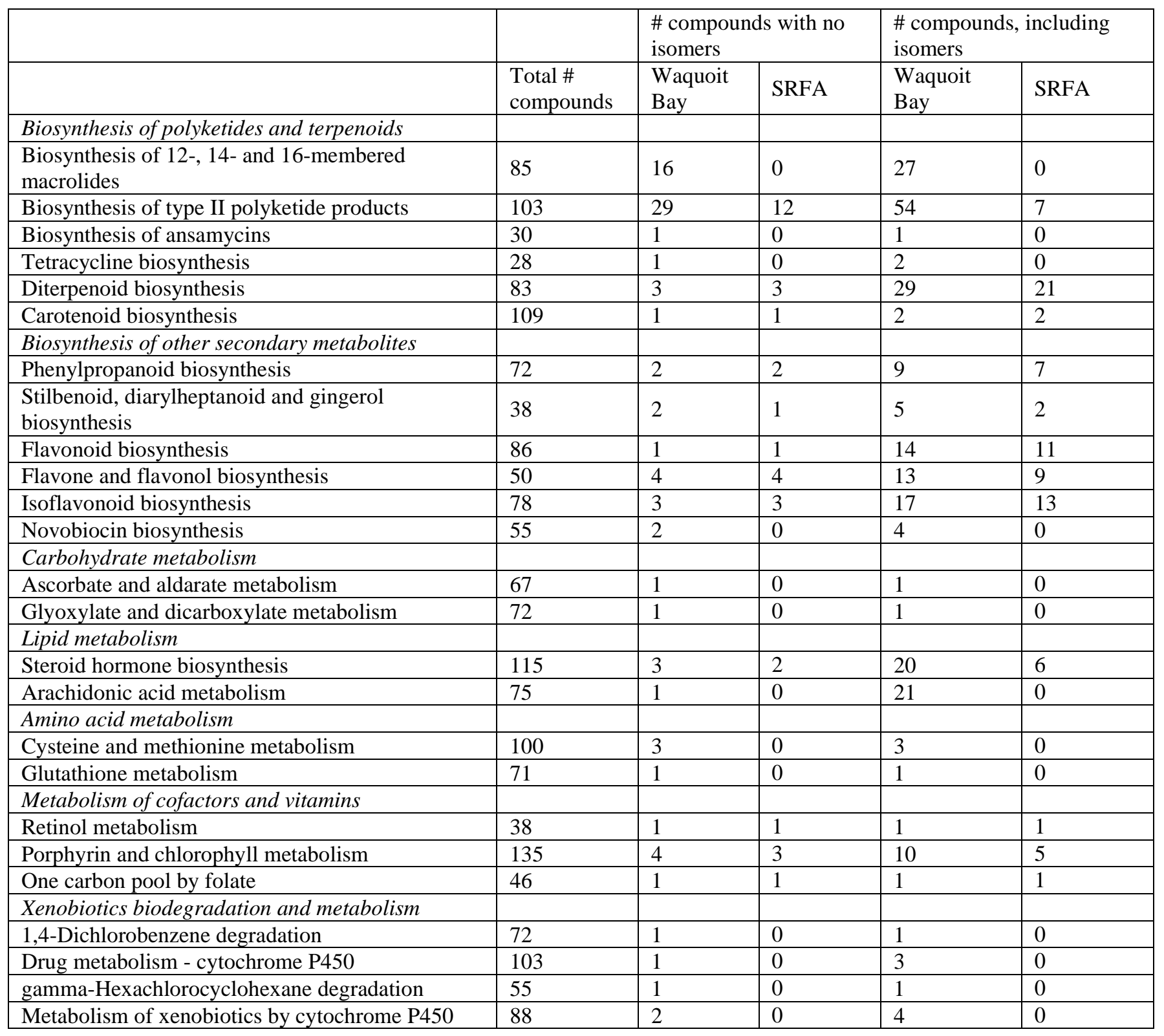




\section{References}

405

406

407

408

409

410

411

412

413

414

415

416

417

418

419

420

421

422

423

424

425

426

427

428

429

430

431

432

433

434

435

436

437

438

Altieri K. E., Turpin B. J., and Seitzinger S. P., (2009) Oligomers, organosulfates, and nitrooxy organosulfates in rainwater identified by ultra-high resolution electrospray ionization FTICR mass spectrometry. Atmos. Chem. Phys. 9, 2533-2542.

Aravena R. and Wassenaar L. I., (1993) Dissolved organic carbon and methane in a regional confined aquifer, southern Ontario, Canada: Carbon isotope evidence for associated subsurface sources. Appl. Geochem. 8, 483-493.

Artinger R., Buckau G., Geyer S., Fritz P., Wolf M., and Kim J. I., (2000) Characterization of groundwater humic substances: influence of sedimentary organic carbon. Appl. Geochem. 15, 97-116.

Beck A. J., Tsukamoto Y., Tovar-Sanchez A., Huerta-Diaz M., Bokuniewicz H. J., and SañudoWilhelmy S. A., (2007) Importance of geochemical transformations in determining submarine groundwater discharge-derived trace metal and nutrient fluxes. Appl. Geochem. 22, 477-490.

Bhatia M. P., Das S. B., Longnecker K., Charette M. A., and Kujawinski E. B., (2010) Molecular characterization of dissolved organic matter associated with the Greenland ice sheet Geochim. Cosmochim. Acta 74, 3768-3784.

Bowen J. L., Kroeger K. D., Tomasky G., Pabich W. J., Cole M. L., Carmichael R. H., and Valiela I., (2007) A review of land-sea coupling by groundwater discharge of nitrogen to New England estuaries: Mechanisms and effects. Appl. Geochem. 22, 175-191.

Buckau G., Artinger R., Geyer S., Wolf M., Fritz P., and Kim J. I., (2000) Groundwater in-situ generation of aquatic humic and fulvic acids and the mineralization of sedimentary organic carbon. Appl. Geochem. 15, 819-832.

Chang Y.-J., Peacock A. D., Long P. E., Stephen J. R., McKinley J. P., Macnaughton S. J., Hussain A. K. M. A., Saxton A. M., and White D. C., (2001) Diversity and characterization of sulfate-reducing bacteria in groundwater at a uranium mill tailings site. Appl. Environ. Microbiol. 67, 3149-3160.

Chapelle F. H., Bradley P. M., Goode D. J., Tiedeman C., Lacombe P. J., Kaiser K., and Benner R., (2009) Biochemical indicators for the bioavailability of organic carbon in ground water. Ground Water 47, 108-121.

Cole M. L., Kroeger K. D., McClelland J. W., and Valiela I., (2006) Effects of watershed land use on nitrogen concentrations and $\delta^{15} \mathrm{~N}$ in groundwater. Biogeochemistry 77, 199-215.

Cunningham J. J., III, Kinner N. E., and Lewis M., (2009) Protistan predation affects trichloroethene biodegradation in a bedrock aquifer. Appl. Environ. Microbiol. 75, 75887593. 
Dittmar T., Koch B., Hertkorn N., and Kattner G., (2008) A simple and efficient method for the solid-phase extraction of dissolved organic matter (SPE-DOM) from seawater. Limnol. Oceanogr. Meth. 6, 230-235.

Goñi M. A. and Gardner I. R., (2003) Seasonal dynamics in dissolved organic carbon concentrations in a coastal water-table aquifer at the forest-marsh interface. Aquat. Geochem. 9, 209-232.

Gruber D. F., Simjouw J. P., Seitzinger S. P., and Taghon G. L., (2006) Dynamics and characterization of refractory dissolved organic matter produced by a pure bacterial culture in an experimental predator-prey system. Appl. Environ. Microbiol. 72, 41844191.

Hartog N., van Bergen P. F., de Leeuw J. W., and Griffioen J., (2004) Reactivity of organic matter in aquifer sediments: geological and geochemical controls. Geochim. Cosmochim. Acta 68, 1281-1292.

Hutchinson C. R. and Fujii I., (1995) Polyketide synthase gene manipulation: a structurefunction approach in engineering novel antibiotics. Annu. Rev. Microbiol. 49, 201-238.

Jonsson L. M. V., Häggblom P., and Söderhäll K., (1987) Turnover of polyketides in the fungus Alternaria alternata with a possible involvement of peroxidase. Exp. Mycol. 11, 223-230.

Kaiser E., Simpson A. J., Dria K. J., Sulzberger B., and Hatcher P. G., (2003) Solid-state and multidimensional solution-state NMR of solid phase extracted and ultrafiltered riverine dissolved organic matter. Environ. Sci. Technol. 37, 2929-2935.

Kanehisa M., Araki M., Goto S., Hattori M., Hirakawa M., Itoh M., Katayama T., Kawashima S., Okuda S., Tokimatsu T., and Yamanishi Y., (2008) KEGG for linking genomes to life and the environment. Nucleic Acids Res. 36, D480-484.

Kido Soule M. C., Longnecker K., Giovannoni S. J., and Kujawinski E. B., (2010) Impact of instrument and experiment parameters on reproducibility of ultrahigh resolution ESI FTICR mass spectra of natural organic matter. Org. Geochem. 41, 725-733.

Kim S., Simpson A. J., Kujawinski E. B., Freitas M. A., and Hatcher P. G., (2003) High resolution electrospray ionization mass spectrometry and 2D solution NMR for the analysis of DOM extracted by $\mathrm{C}_{18}$ solid phase disk. Org. Geochem. 34, 1325-1335.

Kinner N. E., Harvey R. W., Shay D. M., Metge D. W., and Warren A., (2002) Field evidence for a protistan role in an organically-contaminated aquifer. Environ. Sci. Technol. 36, 4312-4318.

Koch B. P., Dittmar T., Witt M., and Kattner G., (2007) Fundamentals of molecular formula assignment to ultrahigh resolution mass data of natural organic matter. Anal. Chem. 79, 1758-1763. 
Kroeger K. D., Cole M. L., and Valiela I., (2006) Groundwater-transported dissolved organic nitrogen exports from coastal watersheds. Limnol. Oceanogr. 51, 2248-2261.

Kujawinski E. B. and Behn M. D., (2006) Automated analysis of electrospray ionization Fouriertransform ion cyclotron resonance mass spectra of natural organic matter. Anal. Chem. 78, 4363-4373.

Kujawinski E. B., Del Vecchio R., Blough N. V., Klein G. C., and Marshall A. G., (2004) Probing molecular-level transformations of dissolved organic matter: insights on photochemical degradation and protozoan modification of DOM from electrospray ionization Fourier transform ion cyclotron resonance mass spectrometry. Mar. Chem. 92, 23-37.

Kujawinski E. B., Longnecker K., Blough N. V., Del Vecchio R., Finlay L., Kitner J. B., and Giovannoni S. J., (2009) Identification of possible source markers in marine dissolved organic matter using ultrahigh resolution mass spectrometry. Geochim. Cosmochim. Acta 73, 4384-4399.

Lapworth D. J., Gooddy D. C., Butcher A. S., and Morris B. L., (2008) Tracing groundwater flow and sources of organic carbon in sandstone aquifers using fluorescence properties of dissolved organic matter (DOM). Appl. Geochem. 23, 3384-3390.

Madsen E. L., Sinclair J. L., and Ghiorse W. C., (1991) In situ biodegradation: microbiological patterns in a contaminated aquifer. Science 252, 830-833.

Mantini D., Petrucci F., Pieragostino D., Del Boccio P., Di Nicola M., Di Ilio C., Federici G., Sacchetta P., Comani S., and Urbani A., (2007) LIMPIC: a computational method for the separation of protein MALDI-TOF-MS signals from noise. BMC Bioinformatics 8, 101.

Margat J., 1994. Groundwater operations and management. In: Gibert, J., Danielopol, D. L., and Stanford, J. A. Eds.), Groundwater Ecology. Academic Press.

McCune B. M. and Grace J. B., (2002) Analysis of Ecological Communities. MjM Software Design, Gleneden Beach, Oregon.

Mitchell T. K., Alejos-Gonzalez F., Gracz H. S., Danehower D. A., Daub M. E., and Chilton W. S., (2003) Xanosporic acid, an intermediate in bacterial degradation of the fungal phototoxin cercosporin. Phytochemistry 62, 723-732.

Mitchell T. K., Chilton W. S., and Daub M. E., (2002) Biodegradation of the polyketide toxin cercosporin. Appl. Environ. Microbiol. 68, 4173-4181.

Montluçon D. and Sañudo-Wilhelmy S. A., (2001) Influence of net groundwater discharge on the chemical composition of a coastal environment: Flanders Bay, Long Island, New York. Environ. Sci. Technol. 35, 480-486.

Moore W. S., (2010) The effect of submarine groundwater discharge on the ocean. Annual Review of Marine Science 2, 59-88. 
Mulligan A. E. and Charette M. A., (2006) Intercomparison of submarine groundwater discharge estimates from a sandy unconfined aquifer. J. Hydrol. 327, 411-425.

Murphy E. M., Davis S. N., Long A., Donahue D., and Jull A. J. T., (1989) Characterization and isotopic composition of organic and inorganic carbon in the Milk River aquifer. Water.

Santos I. R., Burnett W. C., Dittmar T., Suryaputra I. G. N. A., and Chanton J., (2009) Tidal pumping drives nutrient and dissolved organic matter dynamics in a Gulf of Mexico subterranean estuary. Geochim. Cosmochim. Acta 73, 1325-1339.

Sañudo-Wilhelmy S. A., Rossi F. K., Bokuniewicz H., and Paulsen R. J., (2002) Trace metal levels in uncontaminated groundwater of a coastal watershed: importance of colloidal forms. Environ. Sci. Technol. 36, 1435-1441.

Schmidt F., Elvert M., Koch B. P., Witt M., and Hinrichs K.-U., (2009) Molecular characterization of dissolved organic matter in pore water of continental shelf sediments. Geochim. Cosmochim. Acta 73, 3337-3358.

Schwede-Thomas S. B., Chin Y. P., Dria K. J., Hatcher P., Kaiser E., and Sulzberger B., (2005) Characterizing the properties of dissolved organic matter isolated by XAD and C-18 solid phase extraction and ultrafiltration. Aquatic Sciences 67, 61-71.

Senko M. W., Canterbury J. D., Guan S., and Marshall A. G., (1996a) A high-performance modular data system for fourier transform ion cyclotron resonance mass spectrometry. Rapid Commun. Mass Spectrom. 10, 1839-1844.

Senko M. W., Hendrickson C. L., Paša-Tolić L., Marto J. A., White F. M., Guan S., and Marshall A. G., (1996b) Electrospray ionization fourier transform ion cyclotron resonance at 9.4 T. Rapid Commun. Mass Spectrom. 10, 1824-1828.

Seow K. T., Meurer G., Gerlitz M., Wendt-Pienkowski E., Hutchinson C. R., and Davies J., (1997) A study of iterative type II polyketide synthases, using bacterial genes cloned 
from soil DNA: a means to access and use genes from uncultured microorganisms. $J$. Bacteriol. 179, 7360-7368.

Shen B., (2003) Polyketide biosynthesis beyond the type I, II and III polyketide synthase paradigms. Curr. Opin. Chem. Biol. 7, 285-295.

Sherr E. B., Caron D. A., and Sherr B. F., 1993. Staining of heterotrophic protists for visualization via epifluorescence microscopy. In: Kemp, P. F., Sherr, B. F., Sherr, E. B., and Cole, J. J. Eds.), Handbook of Methods in Aquatic Microbial Ecology. Lewis Publishers, Boca Raton.

Sievert S. M., Kiene R. P., and Schulz-Vogt H. N., (2007) The sulfur cycle. Oceanography 20, 84-90.

Simó R., Archer S. D., Pedrós-Alió C., Gilpin L., and Stelfox-Widdicombe C. E., (2002) Coupled dynamics of dimethylsulfoniopropionate and dimethylsulfide cycling and the microbial food web in surface waters of the North Atlantic. Limnol. Oceanogr. 47, 53-61.

Sleighter R. L. and Hatcher P. G., (2008) Molecular characterization of dissolved organic matter (DOM) along a river to ocean transect of the lower Chesapeake Bay by ultrahigh resolution electrospray ionization Fourier transform ion cyclotron resonance mass spectrometry. Mar. Chem. 110, 140-152.

Sleighter R. L., McKee G. A., and Hatcher P. G., (2009) Direct Fourier transform mass spectral analysis of natural waters with low dissolved organic matter. Org. Geochem. 40, 119125.

Slomp C. P. and Van Cappellen P., (2004) Nutrient inputs to the coastal ocean through submarine groundwater discharge: controls and potential impact. J. Hydrol. 295, 64-86.

Suhre K. and Schmitt-Kopplin P., (2008) MassTRIX: mass translator into pathways. Nucleic Acids Res. 36, W481-484.

Taylor T. V., Mitchell T. K., and Daub M. E., (2006) An oxidoreductase is involved in cercosporin degradation by the bacterium Xanthomonas campestris pv. zinniae. Appl. Environ. Microbiol. 72, 6070-6078.

Tremblay L. B., Dittmar T., Marshall A. G., Cooper W. J., and Cooper W. T., (2007) Molecular characterization of dissolved organic matter in a North Brazilian mangrove porewater and mangrove-fringed estuaries by ultrahigh resolution Fourier Transform-Ion Cyclotron Resonance mass spectrometry and excitation/emission spectroscopy. Mar. Chem. 105, 15-29.

Tso S.-F. and Taghon G., (2006) Protozoan grazing increases mineralization of naphthalene in marine sediment. Microb. Ecol. 51, 460-469. 
Valiela I., Costa J., Foreman K., Teal J. M., Howes B., and Aubrey D., (1990) Transport of groundwater-borne nutrients from watersheds and their effects on coastal waters. Biogeochemistry 10, 177-197.

583 van Beek C. G. E. M. and van der Kooij D., (1982) Sulfate-reducing bacteria in ground water 584 from clogging and nonclogging shallow wells in the Netherlands river region. Ground Water 20, 298-302.

Wassenaar L., Aravena R., Fritz P., and Barker J., (1990) Isotopic composition $\left({ }^{13} \mathrm{C},{ }^{14} \mathrm{C},{ }^{2} \mathrm{H}\right)$ and geochemistry of aquatic humic substances from groundwater. Org. Geochem. 15, 383396.

Wawrik B., Kerkhof L., Zylstra G. J., and Kukor J. J., (2005) Identification of unique type II polyketide synthase genes in soil. Appl. Environ. Microbiol. 71, 2232-2238.

591 Zektser I. S. and Everett L. G., (2004) Groundwater resources of the world and their use. United Nations Educational, Scientific and Cultural Organization, IHP-VI, Series on

594 Groundwater No. 6.

595 
Figure 1

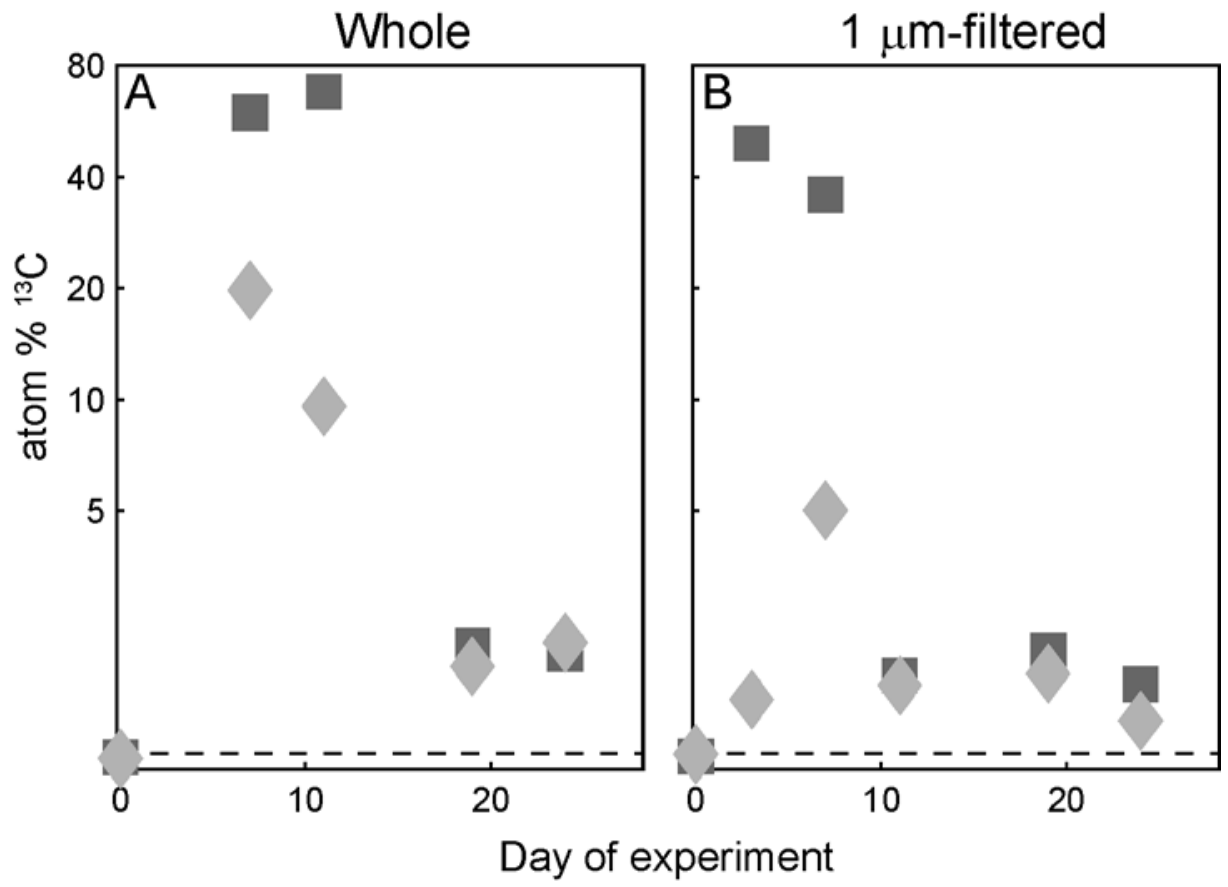


Figure 2

600

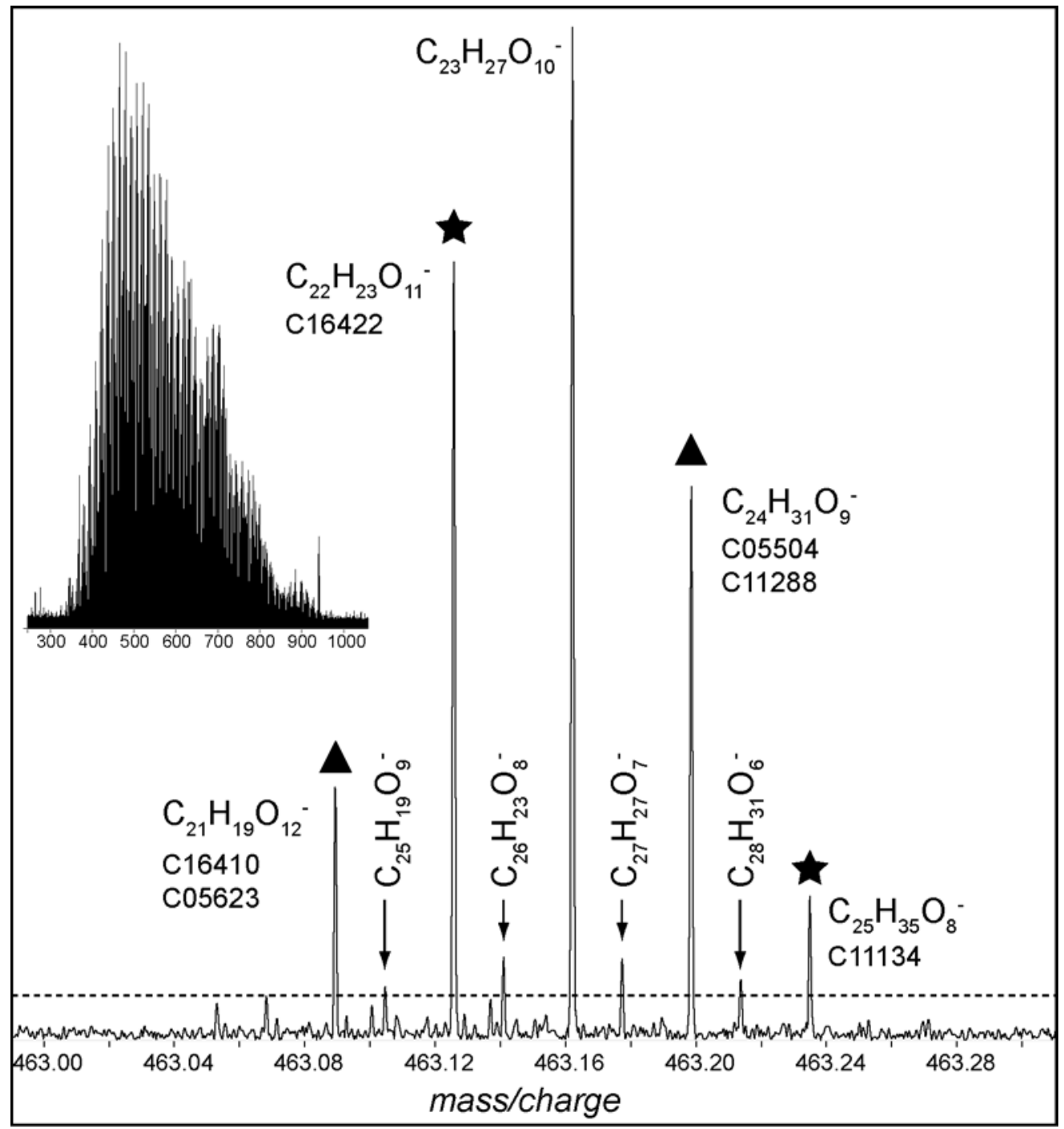


$601 \quad$ Longnecker and Kujawinski

602

Figure 3

A. Positive ion mode

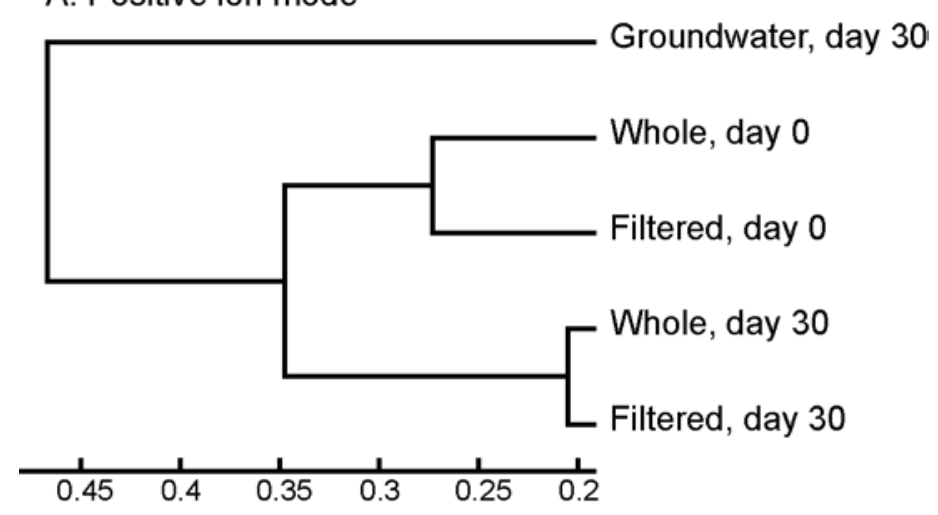

B. Negative ion mode

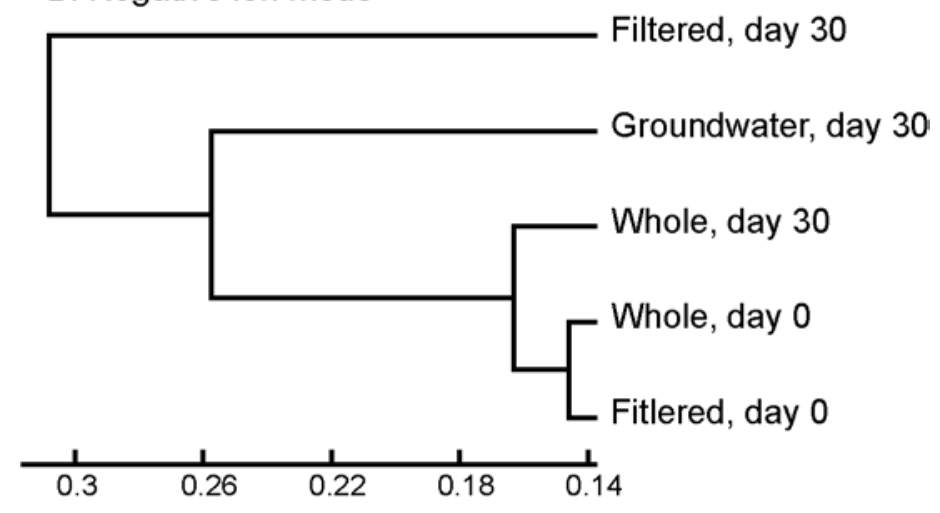

